PEMANFAATAN EKSTRAK REMPAH SERAI Cymbopogon citratus TERHADAP KANDUNGAN ANTIOKSIDAN DAN SIFAT SENSORI PRODUK DARK CHOCOLATE

\title{
UTILIZATION OF LEMONGRASS EXTRACT Cymbopogon citratus AGAINST THE ANTIOXIDANT CONTENT AND SENSORY PROPERTIES OF DARK CHOCOLATE PRODUCTS
}

\author{
A E Pratiwy 1a, I Kusumaningrum 1, Aminullah 1 \\ ${ }^{1}$ Jurusan Teknologi Pangan dan Gizi, Fakultas Ilmu pangan Halal Universitas Djuanda Bogor, \\ Jl. Tol Ciawi No. 1 Kotak pos 35 Ciawi, Bogor 16720 \\ a Korespondensi: Amelya Eka Pratiwy, E-mail: pamelyaeka24@gmail.com \\ (Diterima: 20-09-2019; Ditelaah: 21-09-2019; Disetujui: 29-09-2019)
}

\begin{abstract}
The use of lemongrass extract on dark chocolate products is a diversification of processed chocolate products to increase the antioxidant content and sensory pofile. This research aims to study the effect of comparison chocolate and spice extracts, interaction chocolate and spice extracts comparison of lemongrass to antioxidant compounds and organoleptic characteristics, and to know the chemical properties of selected products. This study consisted of two phases: the first stage is to prepare lemongrass extract with the steam distillation method, the second stage is to make products that include chocolate melting, mixing and molding, then antioxidant tests and organoleptic to determine the selected products with quality sensory tasts and hedonic tests/preferences, chocolate product selected test chemical (moisture, ash, fat, protein, carbohydrate, and calories). The results of the study by testing the antioxidant different uses of chocolate on antioxidant components showed couverture chocolate types have a higher \%inhibition compared to the chocolate kind of compound, the higher the addition of lemongrass extract, the higher antioxidant activity, in the organoleptic tests showed significantly different the parameters of aroma, taste and after taste, but not significantly different from the parameters of melt, interactions between different types of chocolate use, as well as the ratio of chocolate and lemongrass extract significantly influence antioxidant activity, but do not significantly affect organoleptic test results, couverture chocolate products with the addition of $0.3 \%$ spice extract are declared as selected products with antioxidant activity of $83.594 \%, 1.41 \%$ moisture, $1.04 \%$ ash, $20.96 \%$ fat, $3.40 \%$ protein content, $73.19 \%$ carbohydrates and total calories $495 \mathrm{kcal} / 100$ grams.
\end{abstract}

Keywords: Antioxidants, chocolate, lemongrass, sensory pofile.

\section{ABSTRAK}

Penggunaan ekstrak rempah serai pada produk dark chocolate merupakan penganekaragaman produk olahan cokelat meningkatkan kandungan antioksidan dan sifat sensori. Penelitian ini bertujuan mempelajari pengaruh perbandingan cokelat dan ekstrak rempah, interaksi perbandingan cokelat dan ekstrak rempah serai terhadap karakteristik senyawa antioksidan dan organoleptik, serta mengetahui sifat kimia produk terpilih. Penelitian ini terdiri dari 2 tahap yaitu tahap preparasi untuk mempersiapkan ekstrak serai dengan metode destilasi uap, tahap kedua yaitu pembuatan produk yang meliputi pelelehan cokelat, pencampuran dan pencetakan, melakukan uji antioksidan dan uji organoleptik untuk menentukan produk terpilih menggunakan metode uji mutu sensori dan uji hedonik (kesukaan), produk cokelat terpilih dilakukan uji kimia (kadar air, kadar abu, kadar lemak, 
kadar protein, kadar karbohidrat, dan kalori). Hasil dari penelitian berdasarkan pengujian antioksidan perbedaan penggunaan cokelat pada komponen antioksidan menunjukan cokelat jenis couverture memiliki \%inhibisi yang lebih tinggi dibandingkan dengan cokelat jenis compound, semakin tinggi penambahan ekstrak serai maka semakin tinggi aktifitas antioksidannya, pada pengujian organoleptik metode uji mutu sensori menunjukan berbeda nyata terhadap parameter aroma, rasa dan after taste, namun tidak berbeda nyata pada parameter kelelehan, interaksi antara perbedaan penggunaan jenis cokelat serta rasio cokelat dan ekstrak serai berpengaruh nyata terhadap aktifitas antioksidan, namun tidak berpengaruh nyata terhadap hasil pengujian organoleptik, produk jenis cokelat couverture dengan penambahan ekstrak rempah $0,3 \%$ dinyatakan sebagai produk terpilih dengan aktifitas antioksidan sebesar 83,594\%, mengandung kadar air 1,41\%, kadar abu 1,04\%, kadar lemak 20,96\%, kadar protein 3,40\%, karbohidrat by different $73,19 \%$ dan total kalori 495 kkal per 100 gram.

Kata Kunci : Antioksidan, cokelat, serai, profil sensori.

Pratiwy, A. P., Kusumaningrum, I., \& Aminullah. (2019). Pemanfaatan Ekstrak Rempah Serai Cymbopogon citratus terhadap Kandungan Antioksidan dan Sifat sensorik Produk Drak Chocolate. Jurnal Pertanian, 10(2); 80-92.

\section{PENDAHULUAN}

Cokelat merupakan salah satu produk hasil perkebunan berbahan baku biji kakao kemudian diolah menjadi cokelat pasta yang ditambah lemak dan pemanis. Karakter rasa coklat adalah gurih, dengan aroma yang khas sehingga disukai banyak orang khususnya anak-anak dan remaja (Nuraeni, 1995). Jenis pangan berbahan dasar cokelat batang kaya sekali akan antioksidan (katekin, epikatekin, prosianidin, dan polifenol) serupa dengan yang ditemukan didalam sayuran dan teh (Kelishadi, 2005). Antioksidan alami ini diyakini dapat mengurangi radikal bebas dalam tubuh. Kandungan antioksidan katekin dalam cokelat hitam adalah empat kali lipat dari teh (Arts et al, 1999). Akan tetapi tahapan proses pengolahan yang membantu mengurangi rasa sepat (pungent) dan pahit (bitter) pada saat pembuatan cokelat, mengakibatkan menurunnya jumlah kandungan senyawa flavonoid dalam produk yang dihasilkan. Menurut (Sudibyo, 2012) semakin banyak tahap proses pengolahan produk pangan yang dilalui, maka semakin banyak kandungan flavanoid yang hilang.

Rempah adalah segala bahan yang berasal dari tumbuh-tumbuhan, yang pada dasarnya dimanfaatkan untuk memberi cita rasa berbagai jenis makanan atau minuman (Rismunandar, 1992). Rempah memiliki banyak kandungan senyawa-senyawa bioaktif yang salah satu fungsinya sebagai antioksidan, sebagian besar rempahrempahan kaya dengan sumber protein, vitamin (khususnya vitamin $\mathrm{A}, \mathrm{C}$ dan $\mathrm{B}$ ) dan mineral seperti kalsium, fosfor, natrium, kalium danbesi (Navarro et al., 2006). Untuk itu, rempah-rempahan banyak dikembangkan untuk obat herbal karena dipercaya tidak mempunyai efek samping yang berbahaya. Penelitian-penelitian mengenai peran rempah-rempah untuk meningkatkan mutu sensoris makanan dan minuman sudah banyak dilakukan, khususnya yang berkaitan dengan citarasa, aroma dan warna produk. Namun demikian, menurut (Srinivasan, 2005) beberapa dasawarsa belakangan, hasil-hasil penelitian juga menunjukkan adanya pengaruh yang menguntungkan dari rempah-rempah terhadap reaksi-reaksi fisiologis tubuh salah satunya adalah pengaruh hipolipidemia dan antioksidan dari rempah-rempahan yang sudah memberikan implikasi kesehatan yang baik.

Penelitian yang telah dilakukan (Agustina, 2016) untuk meningkatkan kandungan antioksidan dalam produk cokelat dengan 
menambahkan beberapa jenis serbuk rempah rempah. Namun penggunaan serbuk rempah menimbulkan rasa berpasir ketika cokelat dimakan sehingga perlu dilakukan perlakuan pendahuluan pada rempah. Untuk mengatasi hal tersebut dilakukan proses ekstraksi pada rempah sehingga produk yang dihasilkan tidak lagi berpasir. Dalam penelitian kali ini rempah yang akan digunakan yaitu rempah sereh dapur. Selain karena sereh dapur sangat mudah ditemukan, serai memiliki beberapa aplikasi penting dalam kehidupan manusia, salah satunya adalah sebagai antioksidan. Dalam penelitiannya (Mirghani et al.,2012) menyatakan bahwa aktifitas antioksidan dalam essential oil pada batang serai sangat tinggi dengan daya hambat yang efektif sebesar $89 \%$ dan 89,63\%. Sedangkan pada daun serai sedikit lebih rendah dengan aktifitas antioksidan dan antidiabetes berkisar 78,89\% dan 79,26\%. Tujuan umum dari penelitian ini.

Penelitian ini bertujuan untuk mempelajari pengaruh perbandingan cokelat dan ekstrak rempah terhadap karakteristik senyawa antioksidan dan organoleptik, mempelajari interaksi perbandingan cokelat dan ekstrak rempah serai dan jenis cokelat terhadap senyawa antioksidan dan organoleptik serta mengetahui sifat kimia produk cokelat terpilih. Tujuan umum dari penelitian ini adalah penganekaragaman produk cokelat dengan pemanfaatan ekstrak rempah serai.

\section{MATERI DAN METODE}

\section{Alat dan Bahan}

Bahan yang digunakan dalam penelitian ini adalah cokelat couverture dengan merek "Tulip Dark Aura 61\%", cokelat compound dengan merk "Tulip Dark Chocolate Compound", dan ekstrak serai (BALITTRO). Bahan kimia yang digunakan adalah nheksana, DPPH (1, 1-Diphenyl-2Picrylhidrazyl), metanol, etanol, katalis, aquades, asam sulfat (H2SO4), larutan asam borat (H3BO3), larutan natrium hidroksida $(\mathrm{NaOH})$, larutan asam klorida $(\mathrm{HCl}) 0.01 \mathrm{~N}$, larutan indikator (campuran dari metil merah dan bromtimol biru).

Alat yang digunakan dalam penelitian ini adalah kompor, refrigrator, pelelehan cokelat, cetakan cokelat batang, neraca analitik, sudip, spektrofotometri, sentrifugasi, cawan aluminium, cawan porselen, oven, desikator yang berisi bahan pengering (silika gel), penjepit cawan, tanur pengabuan, pembakar burner, pemanas Kjeldahl lengkap yang dihubungkan dengan penghisap uap melalui aspirator, labu Kjeldahl berukuran 30 dan $50 \mathrm{~mL}$, alat distilasi lengkap dengan erlenmeyer berpenampung berukuran 125 $\mathrm{mL}$, buret $50 \mathrm{~mL}$, butir batu didih, erlenmeyer, seperangkat alat Soxhlet lengkap dengan kondensor dan labu lemak, hot plate atau penangat uap, kertas saring, kapas, pipet tetes, beaker glass, dan gelas ukur.

\section{Tempat dan waktu penelitian}

Penelitian ini dilaksanakan di Laboratorium PanganUniversitas Djuanda Bogor, Laboratorium Science Universitas Djuanda Bogor dan Balai Penelitian Tanaman Rempah dan Obat-obatan (BALITTRO). Penelitian ini dilakukan pada bulan Januari - Maret 2019.

\section{Metode Penelitian}

Tahap pertama yaitu tahap preparasi, dilakukan untuk mempersiapakan minyak atsiri yang akan digunakan pada pembuatan cokelat serai dengan metode destilasi uap. Diagram alir pembuatan minyak atsiri dapat dilihat pada Gambar 1. 
Gambar 1. Diangram Alir Pembuatan Ekstrak Serai (Cybopogon citratus) (Balai Penelitian Tanaman Rempah dan Obat-obat, 2014).

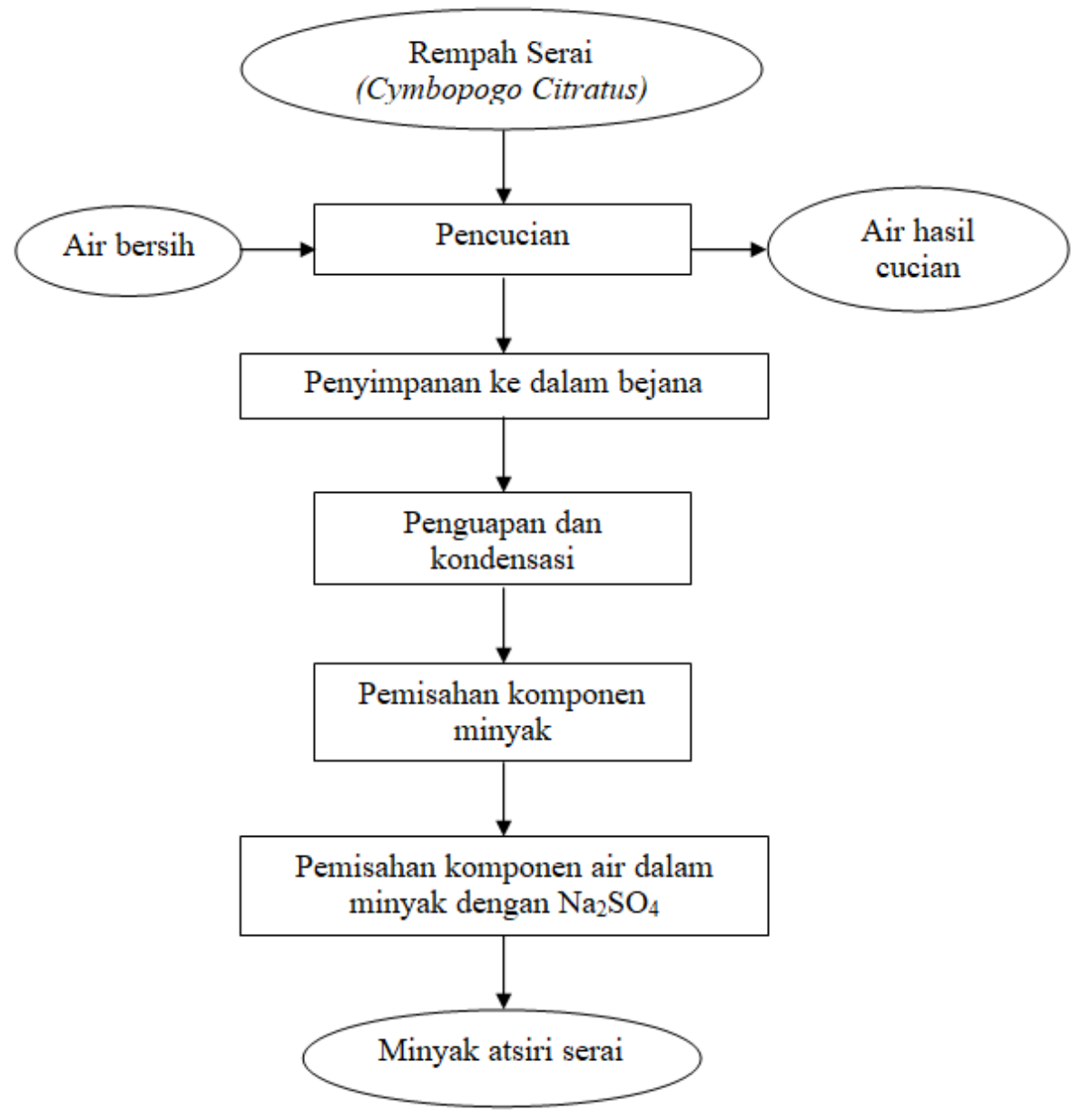

Tahap kedua yaitu tahap pembuatan produk meliputi pelelehan cokelat, pencampuran dan pencetakan. Kemudian dilakukan uji antioksidan dan uji organoleptik untuk menentukan produk terpilih menggunakan metode uji deskriptif dan uji rating hedonik (kesukaan). Pada produk cokelat terpilih dilakukan uji kimia (kadar air, kadar abu, kadar lemak, kadar protein, kadar karbohidrat, dan kalori). Diagram alir proses pembuatan cokelat rempah dapat dilihat pada Gambar 2 dan formulasi cokelat rempah dapat dilihat pada Tabel 1 .
Tabel 1. Formulasi Rasio Cokelat dan Ekstrak Serai.

\begin{tabular}{lcccccc}
\hline \multirow{2}{*}{ Bahan } & \multicolumn{3}{c}{ Couverture (A) } & \multicolumn{3}{c}{ Compound (B) } \\
\cline { 2 - 7 } & A1B1 & A2B1 & A3B1 & A1B2 & A2B2 & A3B2 \\
\hline Cokelat & 99,7 & 99,5 & 99,3 & 99,7 & 99,5 & 99,3 \\
Rempah & 0,3 & 0,5 & 0,7 & 0,3 & 0,5 & 0,7 \\
\hline Total & 100 & 100 & 100 & 100 & 100 & 100 \\
\hline
\end{tabular}


Gambar 2. Diagram Alir Pembuatan produk coklat rempah (modifikasi widyanto, 2014).

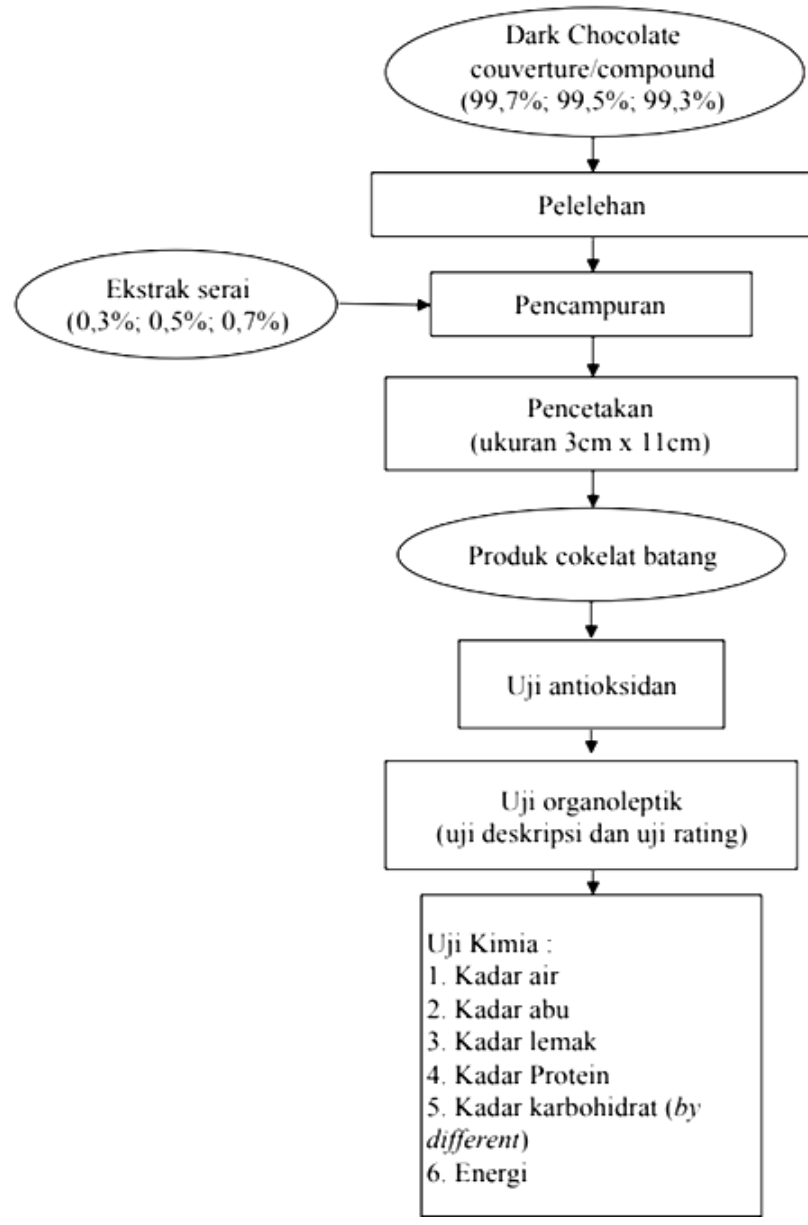

\section{PEMBAHASAN}

\section{Uji Antioksidan}

Data kuantitatif pengujian aktifitas antioksidan cokelat ekstrak rempah serai dilakukan pengujian dengan pengukuran penghambatannya (\%inhibisi). Persen inhibisi yaitu kemampuan suatu bahan untuk menghambat aktifitas radikal bebas yang berhubungan dengan konsentrasi suatu bahan uji. Persen inhibisi ini didapatkan dari perbedaan serapan antara absorbansi DPPH dengan absorbansi sampel yang diukur dengan spektrofotometer Uv-Vis (Andayani, dkk. 2008). Data persentase penghambatan (\%inhibisi) digunakan untuk mencari nilai aktivitas antioksidan dan apabila inhibisi di atas 50\% maka sampel memiliki aktivitas antioksidan. Hasil pengujian aktifitas antioksidan dapat dilihat pada Tabel 2.

Berdasarkan Tabel 2 dapat simpulkan bahwa aktifitas antioksidan pada jenis cokelat couverture memiliki nilai \%inhibisi yang lebih besar dibandingkan dengan jenis cokelat compound, serta semakin tinggi konsentrasi ekstrak rempah serai yang ditambahkan ke dalam cokelat aktifitas antioksidannya semakin meningkat, hal ini ditunjukan dengan persen penghambatan radikal bebas (\%inhibisi) yang meningkat seiring dengan meningkatnya penambahan konsentrasi ekstrak rempah pada cokelat.

Penggunaan jenis cokelat dalam pengolahan penganekaragaman produk cokelat memiliki peran penting terhadap aktifitas antioksidan. Menurut Ibric dan Cavar, (2014) kandungan senyawa fenolik total dan antioksidan pada cokelat tergantung dari komposisi jenis produk cokelat itu sendiri. Penggunaan kakao mass dengan jumlah banyak (65\%) membuat cokelat jenis couverture memiliki kandungan senyawa fenolik yang tinggi sehingga aktifitas antioksidan pada cokelat jenis couverture tinggi (Medeiros, et al., 2015). Muselik et al., (2007) dan Lucena et al., (2010) mengemukakan bahwa aktifitas antioksidan pada suatu pangan memiliki korelasi terhadap kandungan senyawa fenolik, sehingga semakin tinggi senyawa fenolik pada suatu pangan maka tinggi pula aktifitas antioksidan pangan tersebut. Senyawa fenolik yang rendah ada pada cokelat jenis compound, hal ini disebabkan karena cokelat jenis compound terbuat dari cacao powder (20-25\%) dan terdapat komponen susu didalamnya (Medeiros, et al., 2015). Serafini et al., (2003) dan Halliwell, (2003) mengemukakan bahwa susu dapat mengganggu penyerapan antioksidan dari cokelat ketika dilakukan analisa sehingga berpotensi dapat meniadakan manfaat kesehatan yang bisa didapat dari makanan tersebut.

Peningkatan aktifitas antioksidan pada produk disebabkan karena semakin tingginya penambahan konsentrasi ekstrak rempah serai. Semakin besar konsentrasi ekstrak rempah serai maka senyawa fenolik total 
pada produk semakin tinggi, khususnya sitral (Villalobos, 2015). Dalam beberapa tahun terakhir, banyak penelitian yang telah mengevaluasi penggunaan ekstrak rempah sebagai antioksidan alami karena kandungan komponen fenoliknya (Decker, 1998). Alrefaie, (2017) dalam penelitiannya mengemukakan bahwa senyawa fenolik pada ekstrak rempah efektif dapat meningkatkan aktifitas antioksidan serta meningkatkan umur simpan pada produk. Menurut (Ojo, et al., 2006) ekstrak rempah serai dapat menghambat peroksidasi lipid dengan mencegah serangan radikal bebas pada bio membran.

Tabel 2. Hasil Pengujian Aktifitas Antioksidan Produk Cokelat Ekstrak Serai.

\begin{tabular}{cccccc}
\hline \multirow{2}{*}{ Jenis Cokelat } & \multirow{2}{*}{ Kontrol } & \multicolumn{2}{c}{ Rasio Cokelat dan Ekstrak Serai } & \multirow{2}{*}{ Rataan } \\
\cline { 3 - 5 } & & $\mathbf{9 9 , 7 : 0 , 3}$ & $\mathbf{9 9 , 5 : 0 , 5}$ & $\mathbf{9 9 , 3 : 0 , 7}$ & \\
\hline Couverture & 78,069 & $83,594^{\mathrm{d}}$ & $86,440^{\mathrm{b}}$ & $90,179 \mathrm{a}$ & $86,737 \mathrm{x}$ \\
Coumpound & 75,725 & $81,920^{\mathrm{f}}$ & $82,757 \mathrm{e}$ & $83,873^{\mathrm{c}}$ & $82,850 \mathrm{y}$ \\
Rataan & 76,897 & $82,757^{\mathrm{p}}$ & $84,599 \mathrm{q}$ & $87,026^{\mathrm{r}}$ & \\
\hline
\end{tabular}

\section{Uji Organoleptik}

\section{Uji Deskripsi}

Uji deskripsi dilakukan untuk mengidentifikasi karakteristik sensori pada suatu produk. Uji deskripsi rating dilakukan dengan melibatkan 30 panelis semi terlatih. Panelis memberikan penilaian terhadap profil sensori dari sampel menggunakan skala garis tidak terstruktur dengan panjang $10 \mathrm{~cm}$. Atribut sensori yang diuji adalah aroma rempah, rasa pahit, sensasi rasa pedas, mouthfeel dan aftertaste.

\section{Aroma Rempah}

Berdasarkan hasil uji deskriptif panelis terhadap parameter aroma rempah pada produk cokelat ekstrak rempah serai diperoleh nilai rata-rata yang tercantum pada Tabel 3 dimana tingkat aroma rempah cokelat mengarah pada respon terasa aroma khas serai sampai aroma serai agak kuat. Diketahui bahwa semakin banyak penambahan ekstrak rempah serai maka aroma rempah semakin kuat. Senyawa volatil pada rempah-rempahan sangat mempengaruhi mutu produk pangan sehingga kadang dapat menutupi aroma yang tidak dikehendaki, namun komponen ini dapat hilang seiring dengan lamanya proses pengolahan sehingga dapat mengurangi nilai aroma itu sediri (Semadi dan Wartini, 2015). Selain sebagai antioksidan, antibakteri, antijamur dan antikanker komponen senyawa ekstrak serai seperti sitronellal, geraniol, dan sitronellol merupakan senyawa spesifik yang membuat aroma serai pada produk terasa kuat (Bota W et al., 2015).

Tabel 3. Hasil Rata-Rata Uji Deskripsi Produk Cokelat Ekstrak Serai Terhadap Parameter Aroma Rempah

\begin{tabular}{lcccc}
\hline \multirow{2}{*}{$\begin{array}{l}\text { Jenis } \\
\text { Cokelat }\end{array}$} & \multicolumn{3}{c}{ Rasio Cokelat dan } & \\
\cline { 2 - 4 } & $\mathbf{9 9 , 7 : 0 , 3}$ & $\mathbf{9 9 , 5 : 0 , 5}$ & $\mathbf{9 9 , 3 : 0 , 7}$ & \\
\hline Couverture & $5.52^{\mathrm{b}}$ & $6.08^{\mathrm{bc}}$ & $6.95^{\mathrm{c}}$ & $6.18^{\mathrm{x}}$ \\
Coumpound & $4.50^{\mathrm{a}}$ & $5.12^{\mathrm{ab}}$ & $5.80^{\mathrm{b}}$ & $5.14^{\mathrm{y}}$ \\
Rataan & $5.01^{\mathrm{p}}$ & $5.60^{\mathrm{p}}$ & $6.38^{\mathrm{q}}$ & \\
\hline
\end{tabular}

Keterangan: notasi huruf berbeda pada tabel menunjukkan berbeda nyata pada taraf kepercayaan $\alpha=0,05$.

\section{Rasa}

\section{Rasa Pahit}

Berdasarkan hasil uji deskriptif panelis terhadap parameter rasa pahit pada produk cokelat ekstrak rempah serai diperoleh nilai rata-rata yang tercantum pada Tabel 8 dimana tingkat rasa pahit cokelat mengarah pada respon terasa pahit sampai agak terasa pahit. Rasa pahit adalah cita rasa khas alami yang terasa dari dalam cokelat. Rasa pahit pada cokelat seringkali rancu dengan sensasi rasa sepat karena orang tidak sepenuhnya mengerti sifat dan perbedaan antara kedua rasa tersebut, terlebih lagi tanin dan polifenol 
dalam cokelat sebegai komponen yang paling bertanggung jawabterhadap rasa sepat dan juga rasa pahit. Komponen-komponen lainnya yang dapat menimbulkan rasa pahit dalam cokelat yaitu alkaloid seperti theobromine, kafein, komponen fenolik, pyrazinebeberapa peptida dan asam amino bebas (Rahmawati, 2016). Menurut (Ariyani F et al., 2008) ekstrak rempah serai juga memiliki karakteristik rasa pahit, sehingga rasa pahit pada produk dapat diakibat karena adanya penambahan ekstrak rempah serai itu sendiri.

Tabel 4. Hasil Rata-Rata Uji Deskripsi Produk Cokelat Ekstrak Serai Terhadap Parameter Rasa Pahit.

\begin{tabular}{lcccc}
\hline \multirow{2}{*}{$\begin{array}{l}\text { Jenis } \\
\text { Cokelat }\end{array}$} & \multicolumn{3}{c}{$\begin{array}{c}\text { Rasio Cokelat dan } \\
\text { Ekstrak Serai }\end{array}$} & Rataan \\
\cline { 2 - 4 } & $\mathbf{9 9 , 7 : 0 ,}$ & $\mathbf{9 9 , 5 : 0 , 5 9 9 , 3 : 0 , 7}$ & \\
\hline Couverture & $4.54^{\mathrm{ab}}$ & $4.25^{\mathrm{a}}$ & $4.26^{\mathrm{a}}$ & $4.35^{\mathrm{x}}$ \\
Coumpound & $5.59^{\mathrm{b}}$ & $5.15^{\mathrm{ab}}$ & $4.57^{\mathrm{ab}}$ & $5.10^{\mathrm{y}}$ \\
Rataan & $5.07^{\mathrm{p}}$ & $4.70^{\mathrm{p}}$ & $4.42^{\mathrm{p}}$ & \\
\hline
\end{tabular}

Keterangan: notasi huruf berbeda pada tabel menunjukkan berbeda nyata pada taraf kepercayaan $\alpha=0,05$.

\section{Sensasi Pedas}

Berdasarkan hasil uji deskriptif panelis terhadap parameter sensasi pedas pada produk cokelat ekstrak rempah serai diperoleh nilai rata-rata yang tercantum pada Tabel 9 dimana tingkat rasa sensasi pedas cokelat mengarah pada respon terasa pedas. Diketahui bahwa semakin banyak penambahan ekstrak rempah serai maka sensasi rasa pedas semakin meningkat hal ini disebabkan karena senyawa volatil pada ekstrak rempah serai (minyak atsiri) memiliki karakteristik rasa yang getir sehingga memberi kesan terasa pahit dan pedas (Guenther, 2006 dan Ariyani, F. et al, 2008).
Tabel 5. Hasil Rata-Rata Uji Deskripsi Produk Cokelat Ekstrak Serai Terhadap Parameter Rasa Sensasi Pedas.

\begin{tabular}{lcccc}
\hline \multirow{2}{*}{$\begin{array}{l}\text { Jenis } \\
\text { Cokelat }\end{array}$} & \multicolumn{3}{c}{ Eksio Cokelat dan } & Rataa \\
\cline { 2 - 4 } & $\mathbf{9 9 , 7 : 0 ,}$ & $\mathbf{9 9 , 5 : 0 ,}$ & $\mathbf{9 9 , 3 : 0 ,}$ & $\mathbf{n}$ \\
\hline Couvertur & $\mathbf{3}$ & $\mathbf{5}$ & $\mathbf{7}$ & \\
$\boldsymbol{e}$ & $2,98^{\mathrm{a}}$ & $3,46 \mathrm{ab}$ & $4,08 \mathrm{bcd}$ & $3,50 \mathrm{x}$ \\
Coumpound & $3,82^{\mathrm{abc}}$ & $4,54 \mathrm{~cd}$ & $4,95 \mathrm{~d}$ & $4,44 \mathrm{y}$ \\
\hline Rataan & $3,40 \mathrm{p}$ & $4,00 \mathrm{pq}$ & $4,51 \mathrm{q}$ & \\
\hline
\end{tabular}

Keterangan: notasi huruf berbeda pada tabel menunjukkan berbeda nyata pada taraf kepercayaan $\alpha=0,05$.

\section{Mouthfeel}

Berdasarkan hasil uji deskriptif panelis terhadap parameter mouthfeel pada produk cokelat ekstrak rempah serai diperoleh nilai rata-rata yang tercantum pada Tabel 10 dimana tingkat aroma rempah cokelat mengarah pada respon cenderung mudah meleleh. Respon panelis terhadap parameter mouthfeel produk pada seluruh formulasi tidak memberikan perbedaan yang signifikan, hal ini disebabkan karena pada perlakuan penambahan ekstrak serai tidak memberikan pengaruh pada kelelehan cokelat ketika dimakan. Kelelehan cokelat dipengaruhi oleh jenis dan jumlah penambahan lemak pada saat pengolahan cokelat. Minyak dan lemak adalah istilah umum untuk semua cairan organik yang tidak larut/bercampur dalam air (hidrofobik) tetapi larut dalam pelarut organik. Minyak atsiri merupakan jenis minyak yang dihasilkan dari tanaman. Ekstrak rempah serai (minyak atsiri) lebih mudah menguap karena kaya akan ikatan ganda dan asam lemak tidakjenuh yang menyusunnya dibandingkan dengan lemak yang kaya akanikatan asam lemak jenuh (Fessenden dan Fessenden, 1997). 
Tabel 6. Hasil Rata-Rata Uji Deskripsi Produk Cokelat Ekstrak Serai Terhadap Parameter Mouthfeel.

\begin{tabular}{lcccc}
\hline \multirow{2}{*}{$\begin{array}{l}\text { Jenis } \\
\text { Cokelat }\end{array}$} & \multicolumn{3}{c}{$\begin{array}{c}\text { Rasio Cokelat dan } \\
\text { Ekstrak Serai }\end{array}$} & \multirow{2}{*}{ Rataan } \\
\cline { 2 - 4 } & $\mathbf{9 9 , 7 : 0 , 3}$ & $\mathbf{9 9 , 7 : 0 , 3}$ & $\mathbf{9 9 , 7 : 0 , 3}$ & \\
\hline Couverture & $5,98^{\mathrm{c}}$ & $5,69^{\mathrm{bc}}$ & $5,93^{\mathrm{c}}$ & $5,87^{\mathrm{x}}$ \\
Coumpound & $4,95^{\mathrm{ab}}$ & $4,72^{\mathrm{a}}$ & $5,55^{\mathrm{abc}}$ & $5,07^{\mathrm{y}}$ \\
\hline Rataan & $5,46^{\mathrm{p}}$ & $5,21^{\mathrm{p}}$ & $5,74 \mathrm{p}^{\mathrm{p}}$ & \\
\hline
\end{tabular}

Keterangan: notasi huruf berbeda pada tabel menunjukkan berbeda nyata pada taraf kepercayaan $\alpha=0,05$.

\section{After Taste}

Berdasarkan hasil uji deskriptif panelis terhadap parameter after taste pada produk cokelat ekstrak rempah serai diperoleh nilai rata-rata yang tercantum pada Tabel 11 dimana tingkat aroma rempah cokelat mengarah pada respon cenderung terasa agak pahit sampai dengan pahit setelah dimakan. Rasa after taste pada cokelat ekstrak rempah serai setelah dimakan yaitu aroma khas rempah serai terasa pada produk cokelat dengan penambahan ekstrak rempah serai sebanyak 0,7\% dimana kandungan atsiri lebih menonjol ketimbang komponen lainnya sehingga aroma yang dihasilkan dari serai lebih terasa dibanding rasa khas pada cokelat (Nur'aeni, 2016).

Tabel 7. Hasil Rata-Rata Uji Deskripsi Produk Cokelat Ekstrak Rempah Serai Terhadap Parameter After Taste

\begin{tabular}{lcccc}
\hline \multirow{2}{*}{$\begin{array}{l}\text { Jenis } \\
\text { Cokelat }\end{array}$} & \multicolumn{3}{c}{ Rasio Cokelat dan } & \\
\cline { 2 - 4 } & $\mathbf{9 9 , 7 : 0 , 3}$ & $\mathbf{9 9 , 7 : 0 , 3}$ & $\mathbf{9 9 , 7 : 0 , 3}$ & \\
\hline Couverture & 3,70 ab & $3,88^{\text {ab }}$ & $3,22^{\mathrm{a}}$ & $3,60 \times$ \\
Coumpound & $4,35^{\mathrm{b}}$ & 3,99 ab & $3,73^{\mathrm{ab}}$ & $4,02^{\times}$ \\
\hline Rataan & $4,03 \mathrm{p}$ & $3,93 \mathrm{p}$ & $3,47 \mathrm{p}$ & \\
\hline
\end{tabular}

Keterangan: notasi huruf berbeda pada tabel menunjukkan berbeda nyata pada taraf kepercayaan $\alpha=0,05$.

\section{Uji Rating Hedonik}

Uji rating dilakukan untuk menentukan konsentrasi ekstrak rempah serai yang paling disukai. Pada uji rating hedonik dilakukan oleh 30 orang panelis semi terlatih, dengan menggunakan skala kategorik skala 7 point, dimana nilai 7 sangat suka dan nilai 1 sangat tidak suka. Atribut sensori yang diuji yaitu meliputi aroma, rasa, kelelehan dan overall.

\section{Aroma}

Berdasarkan hasil uji rating hedonik panelis terhadap parameter aroma pada produk cokelat ekstrak rempah serai diperoleh nilai rata-rata yang tercantum pada Tabel 12, dimana respon terhadap tingkat aroma rempah cokelat mengarah pada respon cenderung agak tidak suka sampai netral. Semakin tinggi penambahan konsentrasi ekstrak rempah serai maka semakin tercium aroma khas rempah serai pada produk tersebut. Hal ini terjadi karena ekstrak rempah serai yang ditambahkan memiliki senyawa aromatik yang mudah menguap dan memiliki aroma yang khas yaitu senyawa sitral (Hernani dan Cristina, 2010).

Tabel 8. Hasil Rata-Rata Uji Hedonik Produk Cokelat Ekstrak Serai Terhadap Parameter Aroma

\begin{tabular}{lcccc}
\hline \multirow{2}{*}{$\begin{array}{l}\text { Jenis } \\
\text { Cokelat }\end{array}$} & \multicolumn{3}{c}{$\begin{array}{c}\text { Rasio Cokelat dan } \\
\text { Ekstrak Serai }\end{array}$} & \multirow{2}{*}{ Rataan } \\
\cline { 2 - 4 } & $\mathbf{9 9 , 7 : 0 , 3}$ & $\mathbf{9 9 , 7 : 0 , 3}$ & $\mathbf{9 9 , 7 : 0 , 3}$ & \\
\hline Couverture & $3,96^{\mathrm{a}}$ & $4,06^{\mathrm{ab}}$ & $3,82^{\mathrm{a}}$ & $3,95^{\mathrm{x}}$ \\
Coumpound & $4,73^{\mathrm{c}}$ & $4,48^{\mathrm{bc}}$ & $4,03^{\mathrm{ab}}$ & $4,42^{\mathrm{y}}$ \\
\hline Rataan & $4,35^{\mathrm{q}}$ & $4,28^{\mathrm{pq}}$ & $3,93^{\mathrm{p}}$ & \\
\hline
\end{tabular}

Keterangan: notasi huruf berbeda pada tabel menunjukkan berbeda nyata pada taraf kepercayaan $\alpha=0,05$.

\section{Rasa}

Berdasarkan hasil uji rating hedonik panelis terhadap parameter rasa pada produk cokelat ekstrak rempah serai diperoleh nilai rata-rata yang tercantum pada Tabel 13, dimana respon terhadap tingkat rasa cokelat ekstrak rempah serai mengarah pada respon cenderung agak tidak suka sampai netral. Rasa pahit adalah cita rasa khas alami yang terasa dari dalam cokelat. Komponenkomponen yang dapat menimbulkan rasa pahit dalam cokelat yaitu tanin dan poli fenol serta alkaloid seperti theobromine, kafein, komponen fenolik, pyrazinebeberapa peptida dan asam amino bebas (Rahmawati, 2016). 
Ekstrak rempah serai juga memiliki karakteristik rasa pahit, sehingga rasa pahit pada produk dapat diakibatkan pula karena adanya penambahan ekstrak rempah serai itu sendiri (Ariyani F et al., 2008).

Tabel 9. Hasil Rata-Rata Uji Hedonik Produk Cokelat Ekstrak Serai Terhadap Parameter Rasa

\begin{tabular}{lcccc}
\hline \multirow{2}{*}{$\begin{array}{l}\text { Jenis } \\
\text { Cokelat }\end{array}$} & \multicolumn{3}{c}{$\begin{array}{c}\text { Rasio Cokelat dan } \\
\text { Ekstrak Serai }\end{array}$} & rataan \\
\cline { 2 - 4 } & $\mathbf{9 9 , 7 : 0 , 3}$ & $\mathbf{9 9 , 7 : 0 , 3}$ & $\mathbf{9 9 , 7 : 0 , 3}$ & \\
\hline Couverture & $3,52^{\mathrm{a}}$ & $3,58^{\mathrm{a}}$ & $3,35^{\mathrm{a}}$ & $3,48^{\mathrm{x}}$ \\
Coumpound & $4,48^{\mathrm{b}}$ & $4,20^{\mathrm{b}}$ & $3,43^{\mathrm{a}}$ & $4,04^{\mathrm{y}}$ \\
\hline Rataan & $4,00^{\mathrm{q}}$ & $3,89^{\mathrm{q}}$ & $3,39 \mathrm{p}$ & \\
\hline
\end{tabular}

Keterangan: notasi huruf berbeda pada tabel menunjukkan berbeda nyata pada taraf kepercayaan $\alpha=0,05$.

\section{Mouth Feel/Kelelehan}

Berdasarkan hasil uji rating hedonik panelis terhadap parameter kelelehan pada produk cokelat ekstrak rempah serai diperoleh nilai rata-rata yang tercantum pada Tabel 14, dimana respon terhadap tingkat kelelehan cokelat ekstrak rempah serai mengarah pada respon netral. Berdasarkan nilai rata-rata cokelat jenis couverture lebih disukai kelelehannya dibanding cokelat jenis compound karena mudah meleleh ketika dimakan dibandingkan dengan cokelat jenis compound, hal tersebut disebabkan karena lemak yang digunakan pada cokelat jenis couverture yaitu cocoa butter (32-39\%) yang dapat menimbulkan mouthfeel lebih kuat dibandingkan dengan cokelat jenis compound yang menggunakan lemak nabati (20-25\%). Cokelat jenis couverture memiliki titik leleh yang lebih rendah $\left(20^{\circ} \mathrm{C}-22^{\circ} \mathrm{C}\right)$ dibandingkan dengan cokelat jenis compound $\left(28^{\circ} \mathrm{C}-32^{\circ} \mathrm{C}\right)$ (Verna, 2013).

Tabel 10. Hasil Rata-Rata Uji Hedonik Produk Cokelat Ekstrak Serai Terhadap Parameter Kelelehan.

\begin{tabular}{lllll}
\hline \multirow{2}{*}{$\begin{array}{l}\text { Jenis } \\
\text { Cokelat }\end{array}$} & \multicolumn{3}{c}{$\begin{array}{c}\text { Rasio Cokelat dan } \\
\text { Ekstrak Serai }\end{array}$} & \multirow{2}{*}{ Rataan } \\
\cline { 2 - 4 } & $\mathbf{9 9 , 7 : 0 , 3}$ & $\mathbf{9 9 , 7 : 0 , 3}$ & $\mathbf{9 9 , 7 : 0 , 3}$ & \\
\hline Couverture & $4,78^{\mathrm{a}}$ & $4,95^{\mathrm{a}}$ & $4,80^{\mathrm{a}}$ & $4,84^{\mathrm{x}}$ \\
Coumpound & $4,65^{\mathrm{a}}$ & $4,77^{\mathrm{a}}$ & $4,72^{\mathrm{a}}$ & $4,71^{\mathrm{x}}$ \\
\hline Rataan & $4,72^{\mathrm{p}}$ & $4,86^{\mathrm{p}}$ & $4,76^{\mathrm{p}}$ & \\
\hline
\end{tabular}

Keterangan: notasi huruf berbeda pada tabel menunjukkan berbeda nyata pada taraf kepercayaan $\alpha=0,05$.

\section{After Taste}

Berdasarkan hasil uji rating hedonik panelis terhadap parameteraftertaste pada produk cokelat ekstrak rempah serai diperoleh nilai rata-rata yang tercantum pada Tabel 15, dimana respon terhadap tingkat aftertaste cokelat ekstrak rempah serai mengarah pada respon cenderung agak tidak suka. Rasa after taste pada produk setelah dimakan yaitu aroma khas rempah seraiterasa pada produk cokelat dengan penambahan ekstrak rempah serai sebanyak $0,7 \%$ dimana kandungan astrisi lebih menonjol ketimbang komponen lainnya sehingga aroma yang dihasilkan dari serai lebih terasa dibanding rasa khas pada cokelat (Nur'aeni, 2016).

Tabel 1. Hasil Rata-Rata Uji Hedonik Produk Cokelat Ekstrak Rempah Serai Terhadap Parameter AfterTaste

\begin{tabular}{lcccc}
\hline \multirow{2}{*}{$\begin{array}{l}\text { Jenis } \\
\text { Cokelat }\end{array}$} & \multicolumn{3}{c}{$\begin{array}{c}\text { Easio Cokelat dan } \\
\text { Ekstrak Serai }\end{array}$} & rataan \\
\cline { 2 - 4 } & $\mathbf{9 9 , 7 : 0 , 3}$ & $\mathbf{9 9 , 7 : 0 , 3}$ & $\mathbf{9 9 , 7 : 0 , 3}$ & \\
\hline Couverture & $3,47^{\mathrm{a}}$ & $3,70 \mathrm{ab}$ & $3,50^{\mathrm{a}}$ & $3,56^{\mathrm{x}}$ \\
Coumpound & $4,35^{\mathrm{c}}$ & $4,10^{\mathrm{bc}}$ & $3,42^{\mathrm{a}}$ & $3,96^{\mathrm{y}}$ \\
\hline Rataan & $3,91^{\mathrm{q}}$ & $3,90^{\mathrm{q}}$ & $3,46^{\mathrm{p}}$ & \\
\hline
\end{tabular}

Keterangan: notasi huruf berbeda pada tabel menunjukkan berbeda nyata pada taraf kepercayaan $\alpha=0,05$.

\section{Uji Kimia}

Berdasarkan penelitian yang telah dilakukan produk terpilih ditentukan berdasarkan hasil pengujian aktifitas antioksidan dan uji organoleptik maka diputuskan produk cokelat jenis couverture dengan konsentrasi ekstrak rempah serai 0,3\% sebagai produk terpilih. Selanjutnya produk terpilih tersebut dilakukan uji kimia meliputi kadar air, kadar abu, kadar lemak, kadar protein, kadar karbohidrat by different dan total kalori. 
Tabel 2. Hasil uji kimia produk terpilih

\begin{tabular}{lc}
\hline & $\begin{array}{c}\text { Couverture } \\
\text { ekstrak } \\
\text { Pengujian }\end{array}$ \\
& $0,3 \%$ \\
\hline Kadar Air (\%) & 1,41 \\
Kadar Abu (\%) & 1,04 \\
Kadar Lemak (\%) & 20,96 \\
Kadar Protein (\%) & 3,40 \\
Karbohidrat by & 73,19 \\
different (\%) & \\
Total Kalori (kkal) & 495 \\
\hline
\end{tabular}

Hasil analisis proksimat cokelat jenis couverture dengan konsentrasi ekstrak rempah serai $0,3 \%$ merupakan hasil rata-rata dari dua kali pengulangan.

Hasil Pengujian kadar air pada produk cokelat jenis couverture dengan konsentrasi ekstrak rempah serai $0,3 \%$ yaitu $1,41 \%$. Menurut Borchers (2000) proses conching pada saat pengolahan cokelat dari biji kakao akan mempengaruhi \% kadar air produk. Kadar air maksimal pada produk cokelat yaitu 5\% (Widayati, 2013). Kadar air merupakan syarat utama mutu produk karena kandungan air dalam bahan pangan akan mempengaruhi data tahan pangan tersebut terhadap serangan mikroba (Winarno, 2004).

Kadar abu pada produk cokelat jenis couverture dengan konsentrasi ekstrak rempah serai $0,3 \%$ didapat $1,04 \%$. Menurut Ieggli et al., (2011) pengujian kadar abu dilakukan untuk mengetahui ada komposisi mineral pada suatu pangan. Afoakwa et al., (2007) mengemukakan bahwa cokelat merupakan sumber mineral yang baik terutama kalium, magnesium, dan zat besi.

Pada pengujian kadar lemak produk didapat hasil $20,96 \%$. Nilai tersebut belum memenuhi standar syarat mutu cokelat dan produk-produk cokelat (>35\%) (SNI 7934:2014). Penambahan lemak dapat meningkatkan cita rasa dan mutu pada produk, selain itu lemak memiliki peran penting untuk menambah kalori (Winarno, 1991). Menurut Latif (2013) lemak yang digunakan pada produk merupakan lemak yang aman dikonsumsi karena terdiri dari $33 \%$ asam oleat, $25 \%$ asam palmitat, dan $33 \%$ asam stearat.

Kadar protein pada produk cokelat jenis couverture dengan konsentrasi ekstrak rempah serai $0,3 \%$ didapat 3,40\%. Pada dasarnya biji kakao kaya akan protein antara $10-15 \%$ namun pada saat fermentasi dan pemeraman buah protein (Afoakwa et al., 2011).Kadar protein di dalam suatu produk pangan menentukan mutu produk itu sendiri.Protein dapat mengalami kerusakan oleh pengaruh panas, reaksi kimia dan asam atau basa, goncangan dan sebab lainnya (Winarno, 1980).

Kadar karbohidrat pada produk cokelat jenis couverture dengan konsentrasi ekstrak rempah serai $0,3 \%$ ditentukan dengan metode by difference yaitu dengan perhitungan melibatkan kadar air, kadar abu, kadar protein dan kadar lemak.Hasil yang didapat pada produk cokelat jenis couverture dengan konsentrasi ekstrak rempah serai 0,3\% yaitu sebesar 73,19\%. Nilai total kalori yang didapat pada produk cokelat jenis couverture dengan konsentrasi ekstrak rempah serai 0,3\% adalah sebesar 495 kkal/100 gram cokelat. Nilai tersebutditentukan dengan cara perhitungan berdasarkan kadar karbohidrat, protein dan lemak. Setiap gram karbohidrat dan protein menyumbangkan energi sebesar 4 kkal, sedangkan setiap gram lemak menyumbangkan energi sebesar 9 kkal.

\section{KESIMPULAN}

\section{Kesimpulan}

Produk jenis cokelat couverture berdasarkan pengujian antioksidan menunjukan \%inhibisi yang tinggi dibandingkan produk dengan jenis cokelat compound. Pada faktor perbedaan penambahan konsentrasi ekstrak rempah serai berdasarkan pengujian aktifitas antioksidan berdasarkan \%inhibisinya menunjukan bahwa semakin tinggi penambahan ekstrak rempah maka semakin meningkat pula aktifitas antioksidan pada produk baik pada cokelat jenis couverture 
maupun compound. Interaksi antara perbedaan penggunaan jenis cokelat dan perbedaan penambahan konsentrasi ekstrak rempah serai berpengaruh nyata terhadap aktifitas antioksidan, namun tidak berpengaruh nyata terhadap hasil pengujian organoleptik.

Berdasarkan hasil penelitian dengan pengujian aktifitas antioksidan dan uji organoleptik dihasilkan produk jenis cokelat couverture dengan penambahan ekstrak rempah 0,3\% yang mengandung kadar air sebanyak 1,41\%, kadar abu 1,04\%, kadar lemak 20,96\%, kadar protein 3,40\%, karbohidrat by different $73,19 \%$ dan total kalori 495 kkal per 100 gram.

\section{Saran}

Perlu dilakukan perlakuan pendahuluan pada tahap ekstraksi rempah sehingga dapat meminimalisir aroma, rasa dan after taste pada produk tanpa mengurangi kandungan senyawa antioksidan.

\section{DAFTAR PUSTAKA}

Afoakwa, E.O., Paterson, A. and Fowler, M. 2007. Factors influencing rheological and textural qualities in chocolate - a review. Trends in Food Science \& Technology. 18; 290-298.

Agustiana, S. 2016. Penganekaragaman produk cokelat dengan pemanfaatan rempah jahe (Zingiber officiale), kayu manis (Cinnamomum burmani) dan cabai merah (Capsicum annum $L$ ) [Skripsi]. Fakultas Ilmu Pangan Halal, Universitas Djuanda, Bogor. Bogor.

Albak, F. And Tekin, A.R. 2014. Development of functional chocolate with spices and lemon peel powder by using response surface methode. Academic Food Journal. 12 (2): 19-25.

Alspach, G. 2007. The truth is often bittersweet : Chocolste does a heart good. Critical Care Nurse. 27 (1): 11 15.

American Dietetic Association. 2000. Chocolate: facts and fiction. Nutrition fact sheet. Chicago, Ill: American Dietetic Association Foundation.
Andayani, R., Maimunah, \& Lisawati, Y., 2008. Penentuan aktivitas antioksidan, kadar fenolat dan likopen pada buah tomat (Solanum lycopersicum L.). Jurnal Sains dan Teknologi Farmasi. 13, 31-37.

Ariyani, F. Laurentia, E.F., and Felycia, E.S. 2008. Ekstraksi minyak atsiri dari tanaman sereh dengan menggunakan pelarut metanol, aseton, dan n-heksana. Jurnal Widya Teknik. 7(2): 124-133.

Borchers, A.T., Keen, C.L., Hannum, S.M., and Gershwin, M.E. 2000. Cocoa and chocolate: composition, bioavailability, and health implications. Journal of Medicinal Foods. 3:77-103.

Carlson, L.H.C., Machado, C.B.S., Pereira, L.K. and Bolzan, A. 2001. Extraction of lemongrass essential oil with dense carbon dioxide. Journal of Supercritical Fluids. 21: 33-39.

Decker, E. 1998. Strategies for manipulating the prooxidative/antioxidative balance of foods to maximize oxidative stability. Trends Food Science and Technology. 9:241-248.

Fessenden, R.J. and Fessenden, J.S. 1999. Kimia Organik, Jilid 1, Edisi ketiga. Penerbit Erlangga, Jakarta.

Guenther, E. 2006. Minyak Atsiri I. Universitas Indonesia Press. Jakarta.

Halliwell, B. 2003. Plasma antioxidants (communication arising): Health benefits of eating chocolate?. J. Nature. 426, 787-787.

Hernani dan Christina, W. 2010. Kandungan bahan aktif jahe dan pemanfaatannya dalam bidang kesehatan. Balai Besar Pascapanen. Bogor.

Ibrić, A. and Ćavar, S. 2014. Phenolic compounds and antioxidant activity of cocoa and chocolate products. Bulletin of the Chemists and Technologists of Bosnia and Herzegovina. University of Sarajevo. Faculty of Science, Department of Chemistry.42,37-40.

Ieggli, C., Bohrer, D., Nascimento, P. and Carvalho, L. 2011. Determination of sodium, potassium, calcium, magnesium, zinc and iron in emulsified chocolate samples by flame atomic 
absorption spectrometry. J Food Chemistry. 124:1189-1193.

Kelishadi, R.M.D. 2005. Cacao to Cocoa to Chocolate: Healthy Food. Arya Journal. $1(1): 28-34.78-481$.

Latif, R. 2013. Chocolate/cocoa and human health: a review. A review journal in Netherland The Journal of Medicine. 71(2).

Lucena, A.P.S., Nascimento, R.J.B., Maciel, J.A.C. and Tavares, J.X. 2010. Antioxidant activityand phenolic content of selected Brazilian wines. Journal of Food Composition and Analysis. 23, 30-36.

Latif, R. 2013. Chocolate/cocoa and human health: a review. A review journal in Netherland The Journal of Medicine. 71(2).

Lucena, A.P.S., Nascimento, R.J.B., Maciel, J.A.C. and Tavares, J.X. 2010. Antioxidant activityand phenolic content of selected Brazilian wines. Journal of Food Composition and Analysis. 23, 30-36.

Medeiros, N.S., Marder, R.K., Wohlenberg, M.F., Funchal, C. and Dani, C. 2015. Total phenolic content and antioxidant activity of different types of chocolate, milk, semisweet, dark, and soy, in cerebral cortex, hippocampus, and cerebellum of wistar rats. Biochemistry Research International. Department of Biochemistry, Research Center, Brazil. 26 October 2015. 9 pages.

Mirghani, M.E.S., Liyana, Y. and Parveen, J. 2012. Bioactivity analysis of lemongrass (Cymbopogan citratus) essential oil. International Food Research Journal. 19(2): 569-575.

Muselik, J.,Alonso G.M., Martin-Lopez M.P., Ţemlicka M. and Rivas-Gonzalo J.C. 2007. Measurement of antioxidant activity of wine catechins, procyanidins, anthocyanins and pyranoanthocyanins. International Journal of Molecular Sciences. 8, 797-809.

Navarro, J.M., Flores, P., Garrido, C. and Martinez, V. 2006. Changes in the contents of antioxidant compounds in pepper fruits at different ripening stages, as affected bysalinity. J Food Chem. 96: 66-73.

Nuraeni, M.D.R. 2016. Kajian organoleptik dan fisiko kimia olahan coklat rasa jahe dengan tempering dan tanpa tempering. [Tugas Akhir]. Program Studi Teknologi Pangan. Fakultas Teknik. Universitas Pasundan. Bandung.

Nuraeni. 1995. Coklat pembudidayaan, pengolahan, dan pemasaran. Penebar Swadaya. Jakarta.

Ojo, O.O., Kabutu, F.R., Bello, M., and Babayo, U. 2006. Inhibition of paracetamol induced oxidative stress in rats by extracts of lemongrass (Cymbopogon citratus) and green tea (Camellia sinensis) in rats. African Journal of Biotechnology. 5:1227-1232

Rahmawati, F. 2016. Fortifikasi tepung daun kelor (moringa oleifera) dengansusu bubuk dan konsentrasi kayu manis (Cinnamomum Burmani) terhadap karakteristik dark chocolate. Jurnal Teknologi Pangan. Universitas Pasundan. Bandung.

Semadi, N.A. dan Wartini, M. 2015. Senyawa aroma dan cita rasa. Tropical Plant Curriculum Project. Udayana University. Bali.

Serafini M., Bugianesi R., Maiani G., Valtuena S., De Santis S., Crozier A. 2003. Plasma antioxidants from chocolate. J Nature. 424, 1013- 1013.

Srinivasan, K. 2005. Role if spices beyond foot citarasaing: nutraceuticals with multiple health effects. Fiid Rev. 21: 167-188.

Sudibyo, A. 2012. Peran Cokelat Sebagai Produk Pangan Derivat Kakao Yang Menyehatkan. Balai Besar Industri Agro. Jurnal Riset Industri. Vol VI. No 1:23-40.

Verna, R. 2013. Special Articel: The History and Science of Chocolate. Sapienza University of Roma, Italy. Desember 2013. 35(2). 111-121.

Villalobos, M.C. 2015. Antioxidant activity and citral content of different tea preparations of the above-ground parts 
92 | Pratiwy et, al.

of lemongrass (Cymbopogon citratus Stapf.). Journal of Agricultural and Food Chemistry. 46 (3):1111-1115.

Widayati, B.P. 2013. Perbaikan mutu bubuk kakao melalui proses ektraksi lemak dan alkalisasi. Jurnal Teknologi dan Industri Pertanian Indonesia. 5(2).

Widyanto, H. 2014. Formuasi pembuatan cokelat
Pemanfaatan Ekstrak Rempah Serai

(Colocasiaasculenta $[L] \quad$ Schott). Universitas Djuanda Bogor. Jurnal Agroindustri Halal. 1 (1).

Winarno, F.G. 2004. Kimia Pangan dan Gizi. Jakarta : Gramedia Pustaka Utama.

Winarno, F.G. 1980. Enzim Pangan. Pusbangtepa, Bogor. 